\title{
An Assessment of Small Wetland Ecohydrological Dynamics Using Sentinel-2 MSI Derived Spectral Indices in Semi-Arid Environments of South Africa
}

Kgabo Humphrey Thamaga ( $\nabla$ hkgaboreba@gmail.com )

University of the Western Cape https://orcid.org/0000-0002-2305-9975

Timothy Dube

University of the Western Cape

Cletah Shoko

Wits University: University of the Witwatersrand

\section{Research Article}

Keywords: Agricultural practices, Climate variability, High resolution satellite data, Inundation extent, Moisture variation, Surface water presence, Wetland productivity

Posted Date: September 9th, 2021

DOI: https://doi.org/10.21203/rs.3.rs-863296/v1

License: (c) (i) This work is licensed under a Creative Commons Attribution 4.0 International License. Read Full License 


\section{Abstract}

Water presence within small wetlands serve as a determining factor influencing biodiversity productivity and wetland functionality. Small wetlands remain largely unprotected hence, they are more sensitive to frequent exposure to environmental modifications, and are less resilient to changing rainfall patterns, climate change and variability, droughts and changing land use practices. Accurate and up to date spatial and temporal information on changes in surface water and inundation extent becomes imperative for the proper management of these wetlands. Therefore, this study sought to extract and monitor wetland ecohydrological dynamics (surface water and inundation extent) using monthly Sentinel-2 MSI remotely sensed datasets. These dynamics were assessed for the period between July 2020 and June 2021 using the modified normalised difference water index (MNDWI), normalised difference moisture index (NDMI) and normalised difference phenology index (NDPI) derived from Sentinel-2 MSI data. The results showed that the rainy season (Dec 2020 - Feb 2021) had a larger-water coverage extent $\left(10948 \mathrm{~m}^{2}(0.05 \%)\right.$ to $31594 \mathrm{~m}^{2}(0.13 \%)$ ) when compared to the dry season (July 2020: $19157 \mathrm{~m}^{2}(0.04 \%)$ and June $\left.2021: 14429 \mathrm{~m}^{2}(0.03 \%)\right)$. The extent of surface area declined during the dry period due to less rainfall $(0.20 \mathrm{~mm})$ and decreased actual evapotranspiration $(9.90 \mathrm{~mm}-10.43 \mathrm{~mm})$. Further, the NDPI showed a high concentration of wetland vegetation between the months of October 2020 and April 2021. In contrary, higher moisture content was observed between December 2020 to April 2021. The increase in vegetation concentration and moisture content reflects the spatial extent of inundation extent. Wetland water extent, soil moisture, and vegetation condition were assessed with high overall accuracies, ranging between $70.83 \%$ and $97.36 \%$. Overall, the results indicate that small wetlands are characterised with significant variations in levels of inundation and productivity throughout the year.

\section{Introduction}

Wetlands are distinctive and complex ecohydrological systems that occur within a wide range of climatic and topographic environments (Olefeldt et al., 2017; Thamaga et al., 2021). They are defined as areas with low water levels, often near ground surface, characterised by hydrophytic plants during the growing season (Barducci et al., 2009; Liu et al., 2020). Wetlands exist where soil are either saturated or inundated with water for a varying duration (seasonal, inter-annual and decal) and frequency (Li et al., 2015; Zhang et al., 2020). Their ecological processes are strongly influenced by hydrological processes, which control surface water and groundwater recharge dynamics, as well as inputs and outputs of dissolved matter and sediments. Despite covering a smaller proportion of land $(3 \%-8 \%)$, unprotected wetlands distributed across sub-Saharan Africa offer several ecohydrological, and socio-economic benefits (Tiner et al., 2015; Marambanyika \& Beckedahl, 2016; Gxokwe et al., 2020; Dzurume et al., 2021). These wetlands, for example, support the livelihoods of neighbouring rural communities and often-poor households with water, particularly in water-scarce areas. Small wetlands play a critical role in rural economics as they sustain thousands of smallholder farmers for years than larger protected wetlands (Azumi, 2010; Tanko, 2013). In the Southern and Central Africa, 'dambos' continue to support water provision, seasonal agriculture, grazing and fishing (Wood and Thaw, 2013). In areas where access to water is scarce or 
limited during dry season such as the highlands of Ethiopia, wetlands regulate hydrological cycle and enhance water availability in the region (Finlayson et al., 2005). Water availability within wetlands serve as a baseline factor influencing ecosystem biodiversity hotspots. Water presence and wetland spatial extent in a wetland reflect its hydroperiod, which is the period of water level fluctuations that take place in a wetland over time (temporary, seasonal, or permanent) (Jackson et al., 2014). Small wetlands, on the other hand, are under tremendous pressures and are being radically transformed to non-wetland habitats, which may lead to expansion owing to both anthropogenic activities (water diversion, intensive agricultural and industrial development, water abstraction) as well as natural processes (rainfall variability, evapotranspiration, drought, climate change).

Despite the vast expanse and benefits, small wetland ecosystems are highly vulnerable and undergo immense pressure from natural and anthropogenic activities and their survival is threatened. For instance, Marambanyika and Sibanda (2020) demonstrated that wetlands in Zimbabwe decreased in their spatial extent by $3.6 \%$ in 1980 s, when compared with $1.8 \%$ in 2015 . On the other hand, Thamaga et al. (2021) illustrated that Maungani wetland in South Africa lost $43.10 \%$ of its spatial extent in the year 1983 and $13.85 \%$ in 2019 . These studies highlighted that a decline in wetland areas have been mainly attributed to an increase in the built up areas. Other studies revealed that unprotected wetlands are highly vulnerable to environmental and anthropogenic changes through alterations of hydrological regimes, which threaten wetland areas and their-dependent species (Al-Obaid et al., 2017; Bhanga et al., 2020; Wanjala et al., 2020). Natural processes including change in temperature, rainfall patterns, evapotranspiration, drought rate and erosion have fast-tracked wetland water losses (Xia et al., 2017; Chen et al., 2018). It was noted that river channels and associated floodplain wetlands signify spatial and temporal hydrological changes due to flooding and drought rates affecting inundation area (Lambs, 2020). The decrease in the water table disrupts the interactions between surface and groundwater and often shortens the hydrological regime of the flood plain wetlands (Li et al., 2018). On the other hand, anthropogenic modifications resulting from dam construction, increased rural-urban developments because of increased population growth alter hydrological regimes in stream channels and riparian wetlands causing changes in wetland ecohydrological dynamics (Millennium Ecosystem Assessment (MEA), 2005). Gordon et al., (2010) reported that due to intensive agricultural practices, wetlands are drained and approximately $27 \%$ of them are being lost. Furthermore, processes such as desiccation, salinization, eutrophication, contamination, emergence of alien plant species disrupt wetland biodiversity, spatial extent, water quality and availability (Thamaga and Dube, 2018b; 2019). With climate change expected to significantly alter South Africa's rainfall patterns, wetlands will play a more important role than ever before in mitigating the impacts of extreme events like floods and droughts (Knoesen et al. 2009). To date, hydrological dynamics of small wetlands serving nearby communities remains poorly quantified and managed due to the lack of management prioritization. Therefore, there is a need to accurately and frequently monitor small wetlands to put proper management practices in place and support sustainable management of wetland water resources.

Accurate extraction of wetland water and inundation extents is of great significance for planning, monitoring, and protection of these systems. Monitoring wetland ecohydrological dynamics, using 
traditional techniques have proven ineffective due to the difficulties in capturing the spatial heterogeneity and sampling errors. In addition, these methods are costly, time consuming, labour intensive and restricted in terms of spatial coverage (Thamaga and Dube, 2019; Thamaga et al., 2021). The use of satellite-based remote sensing as an alternative can accurately detect and monitor small to larger wetlands in near real time providing observations of hydrological fluxes, inundation spatial extent over time, particularly in regions where in-situ networks are sparse (Tanko, 2013). Several sensors such as Landsat datasets, Sentinel-2 and MODIS have proven promising in studying wetland inundation, surface water estimation, water quality and hydrological cycle (Ali et al., 2016; Thamaga and Dube, 2019; Chiloane et al., 2020; Dzurume et al., 2021).

Previous studies utilised various methods to identify, map, and monitor the distribution of wetlands, surface water bodies, inundation, and non-water areas (Niemuth et al., 2010; Wright, 2010). Some of the water delineation methods used include the inter-spectral relation method, exponential mode, decision tree and thresholding (Zhu et al., 2011; Mondal and Pal, 2018). Furthermore, appropriate spectral bands were combined using various algebraic operations to enhance capabilities to differentiate water coverage areas from non-water bodies. Water indexing techniques to extract surface water bodies include Tasselled Cap Wetness (TCW), Normalised Difference Water Index (NDWI), Land Surface Water Index (LSWI); Modified NDWI (MNDWI), Automated Water Extraction Index (AWEI), Water Ratio Index (WRI), Water Index (WI) for water body extraction (Sarp and Ozcelik, 2017; Chiloane et al., 2020). The efficiency of each for extraction of water bodies was assessed, using the overall accuracy and kappa coefficient (Poulin et al. 2010). These indices perform differently in extracting surface water or inundation areas. For instance, the study by Chiloane et al. (2020) tested multiple indices in Kgalagadi Transfrontier Park of Southern Africa to Pan Inundation and associated seasonal changes within the park. Results from the study showed that MNDWI outperformed other indices in extracting pan inundation. In this study, we sought to extract and monitor surface water and inundation area for small wetlands using monthly Sentinel-2 MSI datasets for the period between July 2020 and June 2021. We further assessed the variability in wetland productivity using the newly developed NDPI as a proxy for vegetation condition.

\section{Materials And Methods \\ 2.1. Study area}

The study was conducted in Maungani wetland located within $30^{\circ} 26^{\prime} 30^{\prime \prime} \mathrm{E}, 22^{\circ} 59^{\prime} 05^{\prime \prime} \mathrm{S}$ and $30^{\circ} 25^{\prime} 45^{\prime \prime} \mathrm{E}$, $22^{\circ} 58^{\prime} 45^{\prime \prime} \mathrm{S}$ longitude and latitude (Fig. 1). The wetland is adjacent to the Dzindzi River, a tributary of Levuvhu River within the Luvumbu quaternary in the Limpopo Transboundary River Basin (LTRB) of Limpopo Province, South Africa. Soutpansberg Mountains influence the climatic condition of the study site (Adeola et al., 2019). The area has an annual rainfall ranging from $7 \mathrm{~mm}$ to $642 \mathrm{~mm}$ yearly and areal temperature ranging between $18^{\circ} \mathrm{C}$ and $37^{\circ} \mathrm{C}$. The annual average relative humidity is $75 \%$. Along site, the wetland area there is agricultural practices taking place such as crops. The Maungani wetland is characterised by stamp lands, as well as marshy vegetation, further, it is dominated by vegetation species 
as: Cyperus papyrus L., Phragmites australis, Echinochloa pyramidalis and Thelypteris interrupta species. The inundation area in the study was also characterised by relating to vegetation coverage (Table 1).

Table 1

Characteristics of Sentinel-2 MSI used in the study

\begin{tabular}{|llll|}
\hline$\#$ & Bands & Wavelength $(\mu \mathrm{m})$ & Resolution $(\mathrm{m})$ \\
\hline 1 & Coastal/ & $0.43-0.46$ & 60 \\
\hline 2 & Blue & $0.44-0.54$ & 10 \\
\hline 3 & Green & $0.55-0.58$ & 10 \\
\hline 4 & Red & $0.65-0.68$ & 10 \\
\hline 5 & RE1 & $0.70-0.73$ & 20 \\
\hline 6 & RE2 & $0.73-0.75$ & 20 \\
\hline 7 & RE3 & $0.77-0.79$ & 20 \\
\hline 8 & NIR & $0.76-0.90$ & 10 \\
\hline $8 \mathrm{~A}$ & NIR narrow & $0.86-0.88$ & 20 \\
\hline 9 & Water vapor & $0.94-0.96$ & 60 \\
\hline 10 & Cirrus & $1.36-1.39$ & 60 \\
\hline 11 & SWIR -1 & $1.54-1.68$ & 20 \\
\hline 12 & SWIR -2 & $2.08-2.32$ & 20 \\
\hline
\end{tabular}

\subsection{Ancillary data}

In this study, meteorological datasets mainly monthly average rainfall data and mean temperature were acquired from the South African Weather Services (SAWS) (https://www.weathersa.co.za/) for Thohoyandou AWS station from July 2020 to June 2021. In addition, the monthly actual evapotranspiration (ET) was obtained from the MODIS data. The ET data was extracted on monthly basis between July 2020 to June 2021 ET was used to assess the amount of evaporation and transpiration lost in Maungani wetland. Meteorological and ET data was used to infer on the observed satellite derived wetland ecohydrological dynamics i.e. inundation extents, surface water variability and vegetation condition.

\subsection{Image acquisition and processing}

Dry and wet seasonal monthly Sentinel-2 MSI images for the period between July 2020 and June 2021, were retrieved from the European Space Agency (ESA) Copernicus Open Access Hub 
(https://scihub.copernicus.eu/). The raw satellite images were pre-processed using the Sentinel Application Platform (SNAP) tool for atmospheric, geometric, and radiometric corrections using Sen2Cor module in SNAP software before being used for the computation spectral metrics. Sentinel-2 MSI data were also converted to Top-of-Atmosphere reflectance value to correct Bottom-of-Atmosphere (BOA). Subsequently, bands 1, 9 and 10 were excluded from the datasets. Then, the images were then resampled at $10 \mathrm{~m}$, using a bilinear method and was subset to the study site extent.

\subsection{Topographic position}

The topographic position in this study was used as a supplementary indicator of wetland occurrence. Digital Elevation Model (DEM) is commonly used to generate topographic metrics such as elevation, slope, aspect, and curvature. In this study, DEM downloaded from https://dwtkns.com/srtm $30 \mathrm{~m} /$ was used to derive Topographic Wetness Index (TWI). TWI is a hydrological parameter that is influenced by flow intensity and water flow accumulation at a hydrographic catchment point (Buchanan et al., 2014). TWI is also an index for soil moisture, which affects growth and composition of vegetation (Gábor et al., 2020). The value of TWI defines the quantity of water content stored in slope constituent materials, which can affect slope instability. Since the aspect is given in degrees with both 0 and 360 degrees facing north, aspect was computed in radians and then sine transformed to range from -1 to 1 . Slope stability factor has a big influence on the mechanism of flash flood. The drainage system and the rainfall that occurs influence this. TWI quantifies tendency of grid cells to receive and accumulate water (Sörensen et al., 2006). This index has been successfully used for studying vegetation patterns and predicting the spatial distribution of plants (Sørensen et al., 2006). Soil type data was retrieved from the ISRIC data hub (http://data.isric.org/). TWI equation is defined as:

$\mathbf{T W I}=\ln \left(\frac{A}{\tan (\beta)}\right)$

Equation (1)

Where $\mathrm{A}$ is the upslope contributing area and $\beta$ is the local slope angle. The higher TWI of a cell, the higher tendency to accumulate water and or inundation area.

\subsection{Measuring wetland hydrology and inundation dynamics using derived spectral indices}

To assess wetland hydrological dynamics for twelve months period (from July 2020 - June 2021), the Modified Normalised Difference Water Index (MNDWI) (Eq. 1) after Xu, (2006) was applied to identify, discriminate, and measure surface water from non-water pixels within the study area. MNDWI is dimensionless and varies between -1 and +1 , where the higher value of MNDWI leads to high water content. These indices provide accurate extraction of open water features better than standard NDWI. According to Ji et al. (2009) the differences in water surface is a difficult task using common threshold value due to dynamic nature that changes depending on sub-pixels of land cover components. The selection of these bands is done to maximize the reflectance of water features by using green light wavelengths and to minimize the low reflectance of SWIR by water features by taking advantage of the 
high reflectance of vegetation and soil features in SWIR band (Du, 2016). The MNDWI value is determined according to the following equation:

$$
M N D W I=\frac{G r e e n-S W I R 1}{G r e e n+S W I R 1}
$$

(Equation 2)

The Normalised Difference Moisture Index (NDMI) shows the moisture variations of the land surface, being highly correlated with the water content of the vegetation and is a good indicator of vegetation change (Rouse et al., 1974; Bernstein, 2012). The NDMI (Bernstein 2012) values ranges between - 1 and 1. The positive value represent high moisture content while negative value represents lower moisture level. NDMI is calculated using the near infrared (NIR) and the short-wave infrared 1 (SWIR 1) bands, according to the following equation:

$$
N D M I=\frac{N I R-S W I R 1}{N I R+S W I R 1}
$$

\section{(Equation 3)}

We assessed wetland vegetation, using the Normalised Difference Phenology Index (NDPI) (Wang et al., 2017). The NDPI is mathematically robust and performs superior to NDVI for differentiating vegetation from the background, theoretically justifying NDPI for spring phenology monitoring. The NDPI (Eq. 4) integrates NIR, red and SWIR bands to extract vegetation information. It ranges between - 1 and 1, where value is closer to -1 represent low vegetation concentration, while value closer to + 1 represent high vegetation concentration.

$$
N D P I=\frac{N I R-(0.74 \times R e d+0.26 \times \operatorname{SWIR} 1)}{N I R+(0.74 \times R e d+0.26 \times \operatorname{SWIR} 1)}
$$

\section{(Equation 4)}

\subsection{Accuracy analysis}

Field data points (60) for non-water area and open water surface were derived using high spatial resolution of Google Earth Images. For duration of this study, sample points were used to validate the water presence within Maungani wetland. Extracted multi-values for MNDWI, NMDI and NDPI were then used to derive classification accuracies. The derived ecohydrological dynamics were then compared with climatological and ET data to establish trends and infer on the observed wetland conditions.

\section{Results}

\subsection{Monthly extraction of surface water derived using MNDWI.}


Wetland water presence and inundation extents were extracted from Sentinel-2 derived indices. Satellite derived wetland water availability vary significantly across the area under study (Figs. 2 and 3). High water presence was recorded in summer season (December 2020 - February 2021) cover an area of $10948 \mathrm{~m}^{2}(0.05 \%), 29772 \mathrm{~m}^{2}(0.12 \%)$ and $31594 \mathrm{~m}^{2}$ (0.13\%), followed by August 2020 and September 2020 covering an area of $12711 \mathrm{~m}^{2}(0.05 \%)$ and $19157 \mathrm{~m}^{2}(0.08 \%)$, respectively. In July 2020 water covered an area of $10312 \mathrm{~m}^{2}(0.04 \%)$, August $2020\left(12711 \mathrm{~m}^{2}(0.05 \%)\right)$ and in September the area increased to $19157 \mathrm{~m}^{2}(0.08 \%)$. During the study period, there was less water coverage was observed during dry period, which had experienced less precipitation with increased temperature variability. The least water presence was observed in November 2020 covering a portion of $5295 \mathrm{~m}^{2}(0.02 \%)$, respectively.

\subsection{Monthly variation of wetland vegetation distribution in relation to inundation periods using NDPI}

The monthly variation in wetland vegetation condition results obtained vary from 0.75 (higher) to -0.49 (low). It can be observed in Fig. 4 that there is a higher concentration of wetland vegetation in northern part of the wetland, with a medium to low configuration in the centre to southern part of the wetland area in July and August 2020, respectively. In September 2020, the larger dominating part of the wetland area has less cover than the northern part, which has medium cover. Wetland vegetation with medium cover is observed from the centre to southern part of Maungani wetland in October 2020. In November 2020, a gradual rise was observed. Furthermore, months of December 2020 to April 2021 had higher vegetation configuration than other months selected in this study. In May and June 2020, there was a reduction in vegetation from the centre of the study towards the southern part of the wetland. Monthly variation, rainfall, temperature, and evapotranspiration trends have an influence on the reduction of wetland vegetation productivity.

\subsection{Monthly variation of moisture within the Maungani wetland area}

Figure 5 shows monthly distribution of moisture content in Maungani wetland area using NDMI. The findings retrieved vary from as low as -0.80 to 0.55 . From the study, it was evidence that months between December 2020 and April 2021 experienced medium to high amount of moisture. In July 2020 and August 2020 high, moderate, and low moisture content were observed in the northern, middle, and southern part of the study. While, in October 2020, November 2020 and June 2021, reduction in moisture content was observed in the northern part of the study area. From the findings, it can be observed that September had the lowest moisture content amongst other months.

\subsection{Accuracy assessment derived to extract surface water coverage, moisture, and vegetation distribution.}


During the study period overall classification accuracy were used to assess extraction capabilities of NDMI, NDPI and MNDWI. The NDPI achieved overall accuracy ranged from 70.83-91.65\%, respectively. While NDMI extracted the moisture within the wetland with high overall accuracy of $95.63 \%$ and $73.47 \%$. Lastly, MNDWI achieved overall accuracy of $78.31 \%$ and $97.36 \%$.

\subsection{Relationship between rainfall pattern, Temperature and Evapotranspiration}

Figure 7 shows a monthly rainfall and mean temperature trend within the Maungani wetland area. It can be observed from the results that the wetland area experiences both low and high rainfall and temperatures. Rainfall was found higher during wet period in December 2020, January 2021 and February 2021 with $18.44 \mathrm{~mm}, 20.45 \mathrm{~mm}$, and $12.85 \mathrm{~mm}$, respectively. During drier periods, rainfall was lower, ranging from $0.20 \mathrm{~mm}$ in May 2021 to $0.60 \mathrm{~mm}$ in July 2020. On the other hand, it can be observed that mean monthly temperature ranged between $16.15^{\circ} \mathrm{C}$ in July and $25.65^{\circ} \mathrm{C}$ in December.

Figure 8 shows the relationship between monthly (July 2020 - June 2021) water extent and actual evapotranspiration (ET). It can be observed that seasonal variation influences the actual ET trends within the wetland, where wet periods experience higher ET than drier periods. Meanwhile, the maximum ET value $(139.16 \mathrm{~mm}$ ) was observed in December 2020 and the minimum ET value of $9.90 \mathrm{~mm}$ in June 2021. During the first six months (July - December 2020), a gradual increase in actual ET trend was observed from $10.43 \mathrm{~mm}$ in August 2020 to a maximum peak of $139.16 \mathrm{~mm}$ in December 2020. Furthermore, the decline in ET was observed between January and June 2021 from $132.39 \mathrm{~mm}$ to 9.90 $\mathrm{mm}$. The results also confirmed that the water availability or coverage had high ET estimate between November 2020 and February 2021, compared to other months.

\section{Discussion}

The increasing number of remotely sensed datasets provide new opportunities for surface water and inundation monitoring of small wetland ecosystems in water-stressed environments. As a result, this study sought to map and assess the monthly wetland water and inundation variations (July 2020 - June 2021), using the Sentinel-2 MSI derived modified normalised difference water index (MNDWI), normalised difference moisture index (NDMI) and normalised difference phenology index (NDPI) in Maungani wetland of Limpopo Transboundary Basin. Sentinel-2 MSI with improved spatial (up to $10 \mathrm{~m}$ on certain bands), temporal (5-days revisit) resolution and freely available provide a detailed and timely information critical to wetland ecologists and water resources managers. This information will strengthen policies, management systems, monitoring, and quantification of neglected small wetland ecosystems serving neighbouring communities and improving rural economies.

\subsection{Small wetland response to monthly rainfall, temperature, and evaporation variability}


Water presence is the main factor controlling wetland ecohydrological dynamics and its functionality. Wetlands respond differently to variations in rainfall, increased evapotranspiration, and temperature. The findings of the study revealed that rainfall, evapotranspiration, temperature, and water coverage trends were higher during summer months (December 2020, January 2021, and February 2021) as compared to dry months (July 2020, August 2020, May 2021, June 2021). The period facilitated wetland water losses and reduced inundation extent through evapotranspiration. The study by Zou et al. (2017) shown that rainfall increases soil moisture content, inundation, and water availability within wetland ecosystems. These provide a clear picture of monthly wetland water fluctuation and inundation area during the period of study. The increase in evapotranspiration rate far exceeds rainfall hence a significant effect in wetland water presence (Dini and Everard, 2016). During the dry periods, evapotranspiration rates increased resulting in significant wetland water losses and wetland vegetation condition (Evenson et al. 2016). Mathews et al. (2019) mentioned that wetland inundation spatial extent is dependent on upstream rainfall and on the ambient trends of evapotranspiration and infiltration or groundwater recharge. Furthermore, the impacts of evapotranspiration due to increased net radiation energy reduces vaporised inundation area as well as moisture availability in small wetlands. Wetland water availability and soil moisture during summer months reflects inundation extent which is strongly related to configuration of vegetation community.

The NDPI results demonstrated similar trends with inundation extent and moisture variability. In cases where Maungani wetland area experience less rainfall and reduced inundation extent resulted in disruption of vegetation productivity. In Poyang lake of China, dramatic changes in hydrological changes condition, which greatly influenced wetland vegetation were observed (Petus et al., 2013). Similar observations were observed by Smith et al. (2011) stating that disconnected streams reduced water presence and inundation extent that affected wetland species diversity and productivity. Water shortages during low rainfall periods and rising temperatures resulted in prolonged drought, leading to the drying up of small wetland ecosystems. The reduction in monthly inundation extent and water presence has a significant influence on wetland vegetation productivity. Drought encroachment within the wetland area increases the susceptibility of wetland vegetation productivity and complicates wetland functionality.

Water deficits in the wetlands represent a severe threat to ecohydrological systems (Lesk et al., 2016). In addition to climate factors, anthropogenic land-use activities alter water flow, water availability and inundation extent. Further, the modifications of the underlying surface characteristics, such as soil moisture, vegetation community, surface roughness, temperature, changes water and heat balance at surface. These have long-term implications to the surrounding communities relying on wetland ecosystem. Excessive wetland water withdrawal for irrigation purpose drains water table beyond its depth and these disrupts vegetation dependent on inundation area, deteriorates and complicates irreversible ecohydrological system (Nevill et al., 2020). The wetlands connected with aquifers experience reduced inundation due to either drying of aquifers or excessive withdrawals for agriculture purposes (Smith et al., 2011). The agricultural malpractices are putting additional strain on wetlands, resulting in drying up of the ecosystem, and the impacts are being exacerbated by increasing temperatures with less precipitation (Martin et al., 2020). 
Our results showed the applicability of Sentinel-2 MSI and metrics (MNDWI, NDPI, NDMI) in assessing wetland water availability and inundation extent in Maungani wetland. The results obtained using MNDWI, NDPI and NDMI managed to retrieve water, vegetation, and moisture information with high classification accuracies during the study period. Satellite extracted ecohydrological data provide baseline information for creating early warnings of impending transitions. With the information gathered from the study, management strategies and decisions can be drawn to protect small wetland ecosystems from further degradation. Although developing countries depends heavily on the ecohydrological system, policies that monitor withdrawal of wetland water need to be enforced to regulate agricultural related activities in these wetlands.

\subsection{Implications of using remotely sensed dataset to study wetland ecohydrological system.}

Existing small wetland ecohydrological systems have deteriorated and/or disappeared, yet there is little information available on wetland water and inundation extent. Furthermore, the hydrological dynamics of unprotected wetlands are influenced by drought or erosion, climatic conditions, and anthropogenic activities, which contribute to the deterioration of wetland ecosystems and make rehabilitation difficult and expensive (Grenfell et al., 2009). Monitoring these ecosystems using Sentinel-2 MSI contributes to a better understanding of ecohydrological systems. However, these images have limitations, such as cloud cover during the wet season, which limits the capability to extract monthly water availability and inundation extent (Whitcraft et al., 2015). Despite a 5-day overpass period, the frequent cloud cover during rainy season, and shadows make accurate monitoring and mapping of wetland water and inundation areas difficult.

\section{Conclusion}

This study assessed monthly variation of wetland water presence and inundation area using monthly Sentinel-2 MSI dataset. Monthly imageries dating from July 2020 - June 2021 were used to extract water and inundation areas using MNDWI, NDPI and NDMI. From the results following conclusions were drawn:

- During the period of study, MNDWI, NDMI and NDPI used achieved overall classification accuracies ranging from $70.83 \%-98 \%$, respectively.

- Between October 2020 and April 2021, findings revealed that there is high moisture and phenological coverage that indicate the wetness within the Maungani wetland area.

- Results derived using MNDWI showed that water covering the Maungani area varies during Winter (July and August 2020), spring (September) and summer season (December 2020, January 2021, and February 2021).

The findings derived from this study provide new insights on small wetland ecosystems. Moisture and phenological information provide better understanding of wetland inundation area which is critical for 
devising sustainable management strategies. Adopting the use of digital technologies at a local level will be critical in safeguarding small wetlands that in this regard remain understudied.

\section{Declarations}

\section{Acknowledgement}

Authors would like to thank the European Space Agency (ESA) Copernicus for provision satellite imagery and University of the Western Cape in South Africa for creating and enabling environment for research. We would also like to express our gratitude to the South African National Space and Agency (SANSA) and Empire Partner Foundation (EPF) Tech Hub for sponsoring and supporting this study.

\section{ORCID:}

Kgabo Humphrey Thamaga $\quad$ : http://orcid.org/0000-0002-2305-9975_

Timothy Dube : : http://orcid.org/0000-0003-3456-8991

Cletah Shoko $\quad$ : http://orcid.org/0000-0003-4222-3539

\section{References}

Al-Obaid S, Samraoui B, Thomas J, El-Serehy HA, Alfarhan AH, Schneider W, O'Connell M (2016) An overview of wetlands of Saudi Arabia: Values, threats, and perspectives. AMBIO, 46(1)

Barducci A, Guzzi D, Marcoionni P, Pippi I (2009) Aerospace wetland monitoring by hyperspectral imaging sensors: A case study in the coastal zone of San Rossore Natural Park. J Environ Manag 90:2278-2286

Bhaga TD, Dube T, Shekede MD, Shoko C (2020) Impacts of Climate Variability and Drought on Surface Water Resources in Sub-Saharan Africa Using Remote Sensing: A Review. Remote Sensing 12(24):4184

Buchanan BP, Fleming M, Schneider RL, Richards BK, Archibald J, Qiu Z, Walter MT (2014) Evaluating topographic wetness indices across central New York agricultural landscapes. Hydrology Earth System Science 18:3279-3299

Ceccato P, Flasse S, Tarantola S, Jacquemond S, Gregoire JM (2001) Detecting vegetation water content using reflectance in the optical domain. Remote Sens Environ 77:22-33

Chen Y, Huang J, Song X, Gao P, Wan S, Shi L, Wang X (2018) Spatiotemporal characteristics of winter wheat waterlogging in the middle and lower reaches of the yangtze river, China. Adv Meteorol. https://doi.org/10.1155/2018/3542103 
Chiloane C, Dube T, Shoko C (2020) Monitoring and assessment of the seasonal and inter-annual pan inundation dynamics in the Kgalagadi Transfrontier Park, Southern Africa. Phys Chem Earth 118119:102905

Cole JJ, Prairie YT, Caraco NF, McDowell WH, Tranvik LJ, Striegl RG, Duarte CM, Kortelainen P, Downing JA, Middelburg JJ, Melack J (2007) Plumbing the Global Carbon Cycle: Integrating Inland Waters into the Terrestrial Carbon Budget, Ecosystems, 10, 172-185, https://doi.org/10.1007/s10021-006-9013-8, 2007

Du Y, Zhang Y, Ling F, Wang Q, Li W, Li X (2016) Water bodies' mapping from Sentinel-2 Imagery with Modified Normalised Difference Water Index at 10-m spatial resolution produced by sharpening the SWIR band. Remote sensing 8:354

Dzurume T, Dube T, Thamaga KH, Shoko C, Mazvimvi D (2021) Use of multispectral satellite data to assess impacts of land management practices on wetlands in the Limpopo Transfrontier River Basin, South Africa. South African Geographical Society, https://doi.org/10.1080/03736245.2021.1941220

Evenson GR, Golden HE, Lane CR, D'Amico, E (2016) An improved representation of geographically isolated wetlands in a watershed-scale hydrologic model, Hydrological Processes, 2016

Feyisa GL, Meilby H, Fensholt R, Proud SR (2014) Automated Water Extraction Index: A new technique for surface water mapping using Landsat imagery. Remote Sens Environ 140:23-35

Finlayson CM, D'Cruz R, Aladin N, Barker D, Beltram G, Brouwer J, Davidson N, Duker L, Junk W, Kaplowitz M (2005) Inland water systems. In: Hassan R, Scholes RJ, Ash N (eds) Ecosystems and Human WellBeing: Current State and Trends, 1. Island Press, Washington, DC, USA, pp 553-583

Fisher A, Flood N, Danaher T (2016) Comparing Landsat water index methods for automated water classification in eastern Australia. Remote Sens Environ 175:167-182

Gordon LJ, Finlayson CM, Falkenmark M (2010) Managing water in agriculture for food production and other ecosystem services. Agriculture Water Management 97:512-519

Government of Zimbabwe (2015) Zimbabwe's Fifth National Report to the Convention on Biodiversity. Harare: Ministry of Environment, Water and Climate; 2015. 18 p

Gxokwe S, Dube T, Mazvimavi D (2020) Multispectral Remote Sensing of Wetlands in Semi-Arid and Arid Areas: A Review on Applications, Challenges and Possible Future Research Directions. Remote Sensing $12: 4190$

Haibo Y, Wang Z, Zhao H, Guo Y (2011) Water body Extraction Methods Study Based on RS and GIS (2011) 3rd international conference on environmental science and information application technology (ESIAT 2011). Procedia Environ Science, 10: 2619-2624 
Han-Qiu X (2005) A study on information extraction of water body with the modified normalized difference water index (MNDWI). Journal of remote sensing. 2005; 5:589-95

Hassan R, Scholes R, Ash N (2005) Ecosystems and human well-being: current state and trends. Island Press, Washington (DC)

Hayashi M, van der Kamp G, Rosenberry DO (2016) Hydrology of Prairie Wetlands: Understanding the Integrated Surface-Water and Groundwater Processes. Wetlands, pp 1-18

Li L, Vrieling A, Skidmore AK, Wang T, Muñoz AR, Turak E (2015) Evaluation of MODIS Spectral Indices for Monitoring Hydrological Dynamics of a Small, Seasonally Flooded Wetland in Southern Spain. Wetlands $35: 851-864$

Liu Q, Liu J, Liu H, Liang L, Cai Y, Wang X, li C (2020) Vegetation dynamics under water-level fluctuations: Implications for wetland restoration. J Hydrol 581:124418

Mahdianpari M, Salehi B, Rezaee M, Mohammadimanesh F, Zhang Y (2018) Very deep convolutional neural networks for complex land cover mapping using multispectral remote sensing imagery. Remote Sens 10:1119

Mondal D, Pal S (2018) Monitoring dual-season hydrological dynamics of seasonally flooded wetlands in the lower reach of Mayurakshi River, Eastern India. Geocarto International 33(3):225-239

Muavhi N, Thamaga KH, Mutoti MI (2021) Mapping groundwater potential zones using Relative Frequency Ratio, Analytical Hierarchy Processes, and their Hybrid models: Case of Nzhelele-Makhado area in South Africa. Geocarto International, http://dx.doi.org/10.1080/10106049.2021.1936212

Olefeldt D, Euskirchen ES, Harden J, Kane E, McGuire AD, Waldrop MP, Turetsky MR (2017) A decade of boreal rich fen greenhouse gas fluxes in response to natural and experimental water table variability. Glob Change Biol 23(6):2428-2440

Poulin B, Davranche A, Lefebvre G (2010) Ecological assessment of Phragmites australis wetlands using multi-season SPOT-5 scenes. Remote Sens Environ 114:1602-1609

Rampheri M, Dube T, Dhau I (2020) Use of remotely sensed data to estimate tree species diversity as an indicator of biodiversity in Blouberg Nature Reserve, South Africa. Geocarto International. DOI:10.1080/10106049.2020.1723717

Sahu AS (2018) Detection of water-logged areas using geoinformatics techniques and relationship study in panskura-tamluk flood plain (India) Nadia - West Bengal. Trans Inst Indian Geogr 40(1):9-24

Sarp G, Ozcelik M (2017) Water body extraction and change detection using time series: a case study of Lake Burdur, Turkey. J Taibah Univ Sci 11(3):381-391 
Shen L, Li C (2010a) Water Body Extraction from Landsat ETM + Imagery Using Adaboost Algorithm. In: Proceedings of 18th International Conference on Geoinformatics, Beijing, pp 1-4

Tafesse M (2003) Small-scale irrigation for food security in sub- Saharan Africa, The ACP-EU Technical Centre for Agricultural and Rural Cooperation (CTA), Ethiopia, 2003

Thamaga KH, Dube T, Shoko C (2021) Advances in satellite remote sensing of wetland ecosystems in sub-Saharan Africa. Geocarto International, 1-22

Thamaga KH, Dube T (2019) Understanding seasonal dynamics of invasive water hyacinth (Eichhornia crassipes) in the Greater Letaba river system using Sentinel-2 satellite data. GIScience Remote Sensing 56(8):1355-1377

Tiner RW, Lang MW, Klemas VV (2015) In Remote Sensing of Wetlands: Applications and Advances Chap. 1. (p. 4). CRC Press. URL: http://www.crcnetbase.com/doi/book/10.1201/b18210 DOI: 10.1201/b18210

Tymków P, Józ'ków G, Walicka A, Karpina M, Borkowski A (2019) Identification of Water Body Extent Based on Remote Sensing Data Collected with Unmanned Aerial Vehicle. Water 11:338

Wang C, Chen J, Wu J, Tang Y, Shi P, Black TA, Zhu K (2017) A snow-free vegetation index for improved monitoring of vegetation spring green-up date in deciduous ecosystems. Remote Sens Environ 196:1-12

Wanjala JA, Sichangi AW, Mundia CN, Makokha GO (2020) Modelling the dry season inundation pattern of Yala Swamp in Kenya. Model Earth Syst Environ 6:2091-2101

Whitcraft AK, Becker-Reshef I, Killough BD, Justice CO (2015) Meeting Earth Observation Requirements for global agricultural monitoring: An Evaluation of the revisit capabilities optical earth observing mission. Remote Sensing, 7(2)

$\mathrm{Xu} \mathrm{H}$ (2006) Modification of normalised difference water index (MNDWI) to enhance open water features in remotely sensed imagery. Int J Remote Sens 27:3025-3033

Zhang Z, Bianchette TA, Meng C, Xu Q, Jiang M (2020) Holocene vegetation-hydrology-climate interactions of wetlands on the Heixiazi Island, China. Sci Total Environ 743:140777

Zhao L, Wu F (2015) Simulation of Runoff Hydrograph on Soil Surfaces with Different Microtopography Using a Travel Time Method at the Plot Scale, PloS one, 10, e0130794, 2015

Zhu X, Cao J, Dai Y (2011) A Decision Tree Model for Meteorological Disasters Grade Evaluation of Flood. In: Proceedings of 4th International Joint Conference on Computational Sciences and Optimization 2011, Kunming and Lijiang, Yunnan, China, 15-19 April 2011. Institute of Electrical and Electronics Engineers, New York, 916-919 
Zou M, Niu J, Kang S, Li X, Lu H (2017) The contribution of human agricultural activities to increasing evapotranspiration is significantly greater than climate change effect over Heihe agricultural region. Sci Rep 7:8805

\section{Tables}

Due to technical limitations, table 1 is only available as a download in the Supplemental Files section.

\section{Figures}

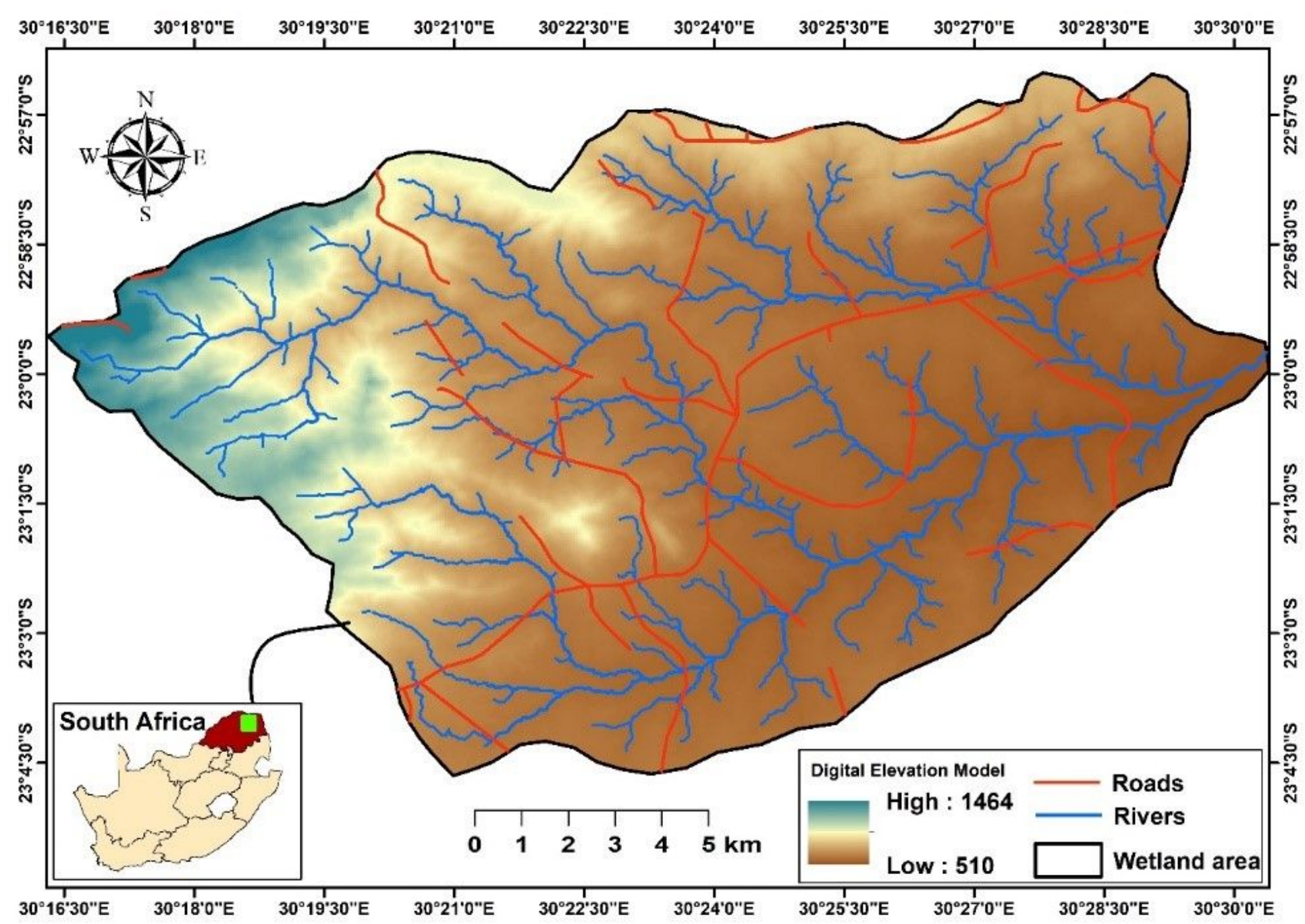

Figure 1

Maungani wetland study area. 

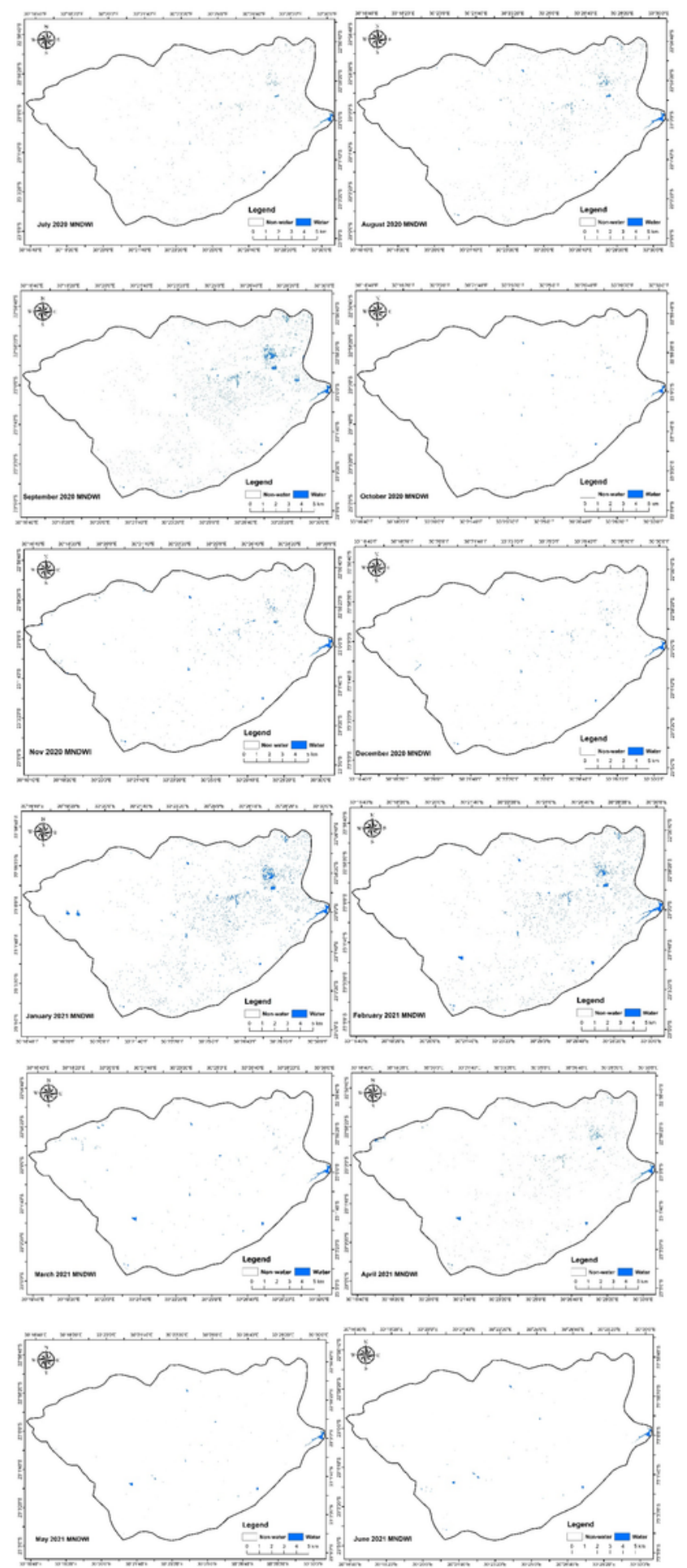

Figure 2

Monthly surface water coverage depicted from July 2020 to June 2020. 


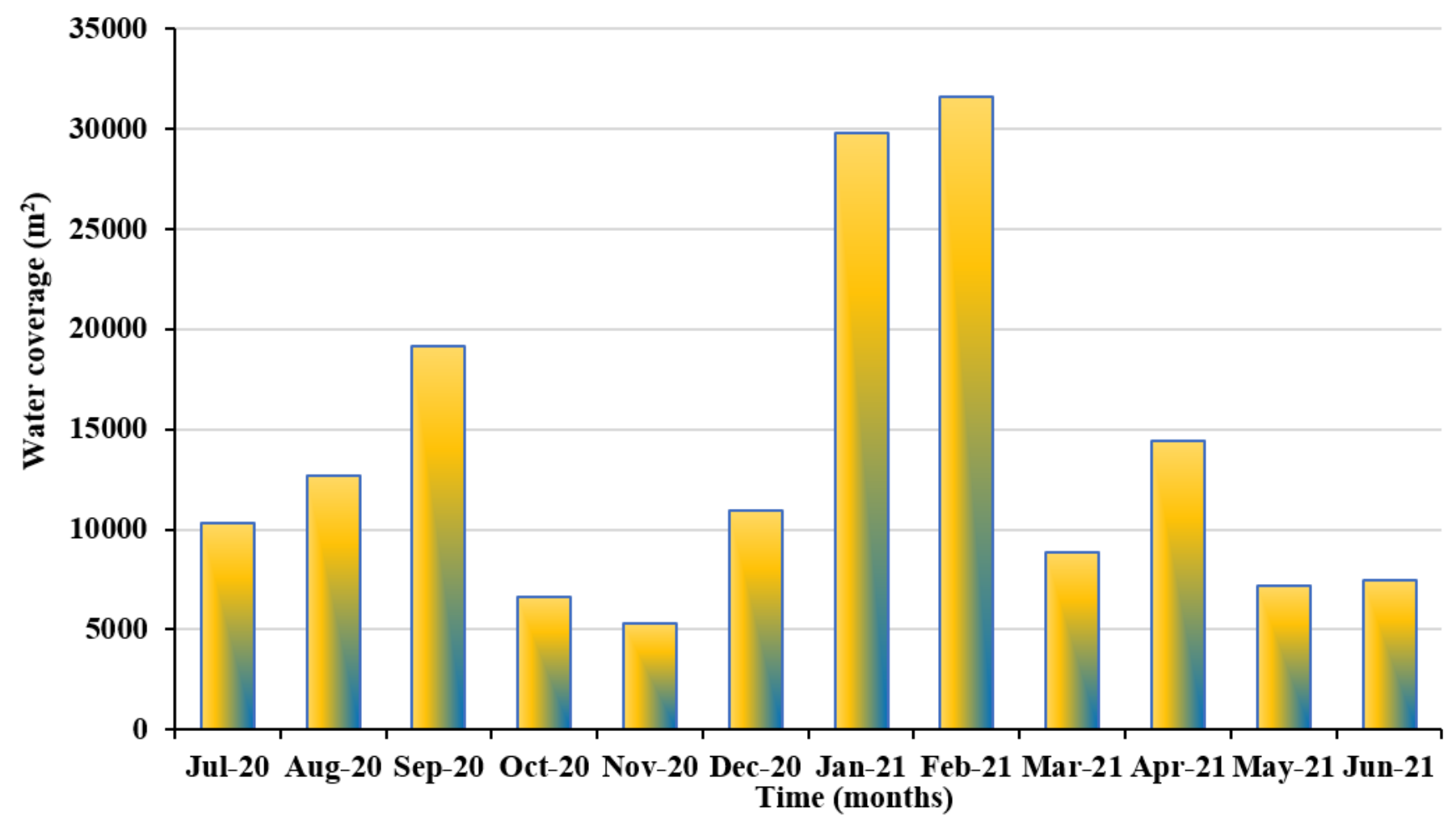

Figure 3

Seasonal variation in wetland water coverage derived using MNDWI. 

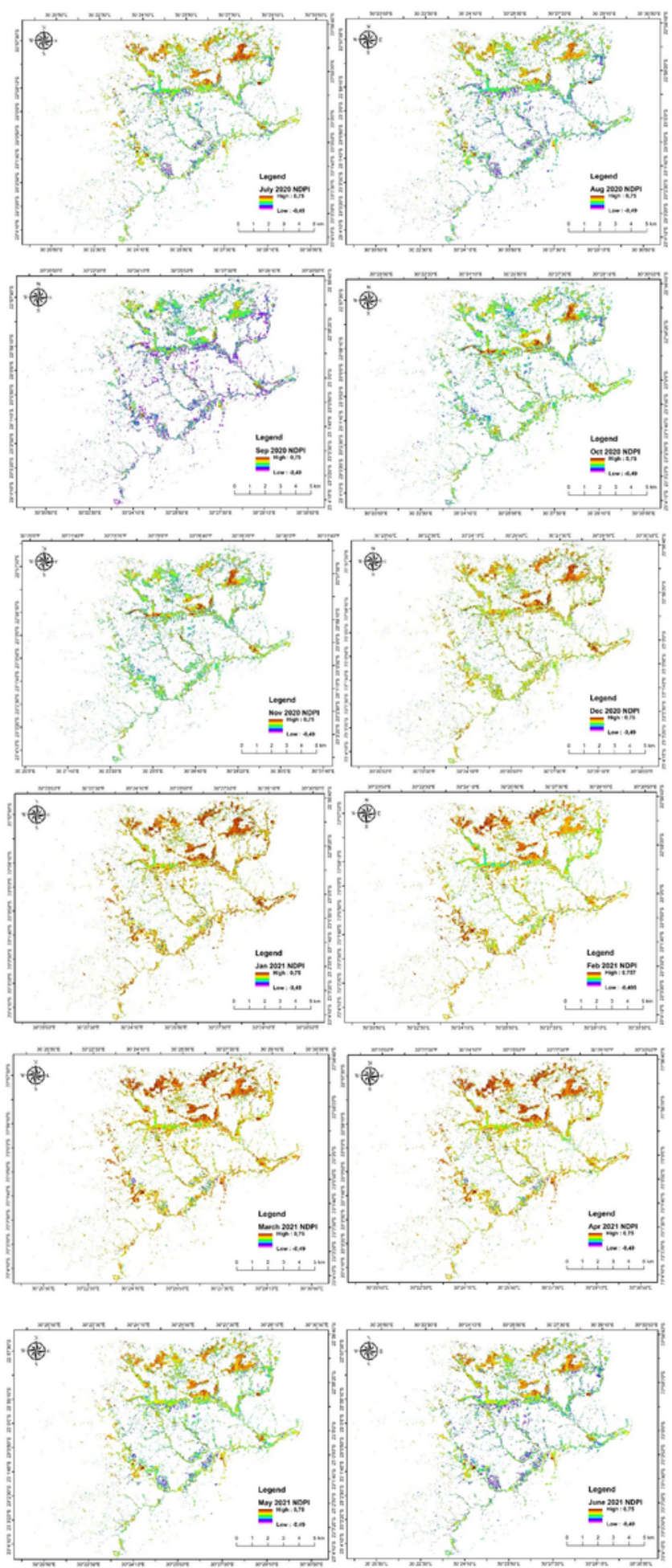

Figure 4

Monthly variation in NDPI as a proxy for wetland vegetation condition. 

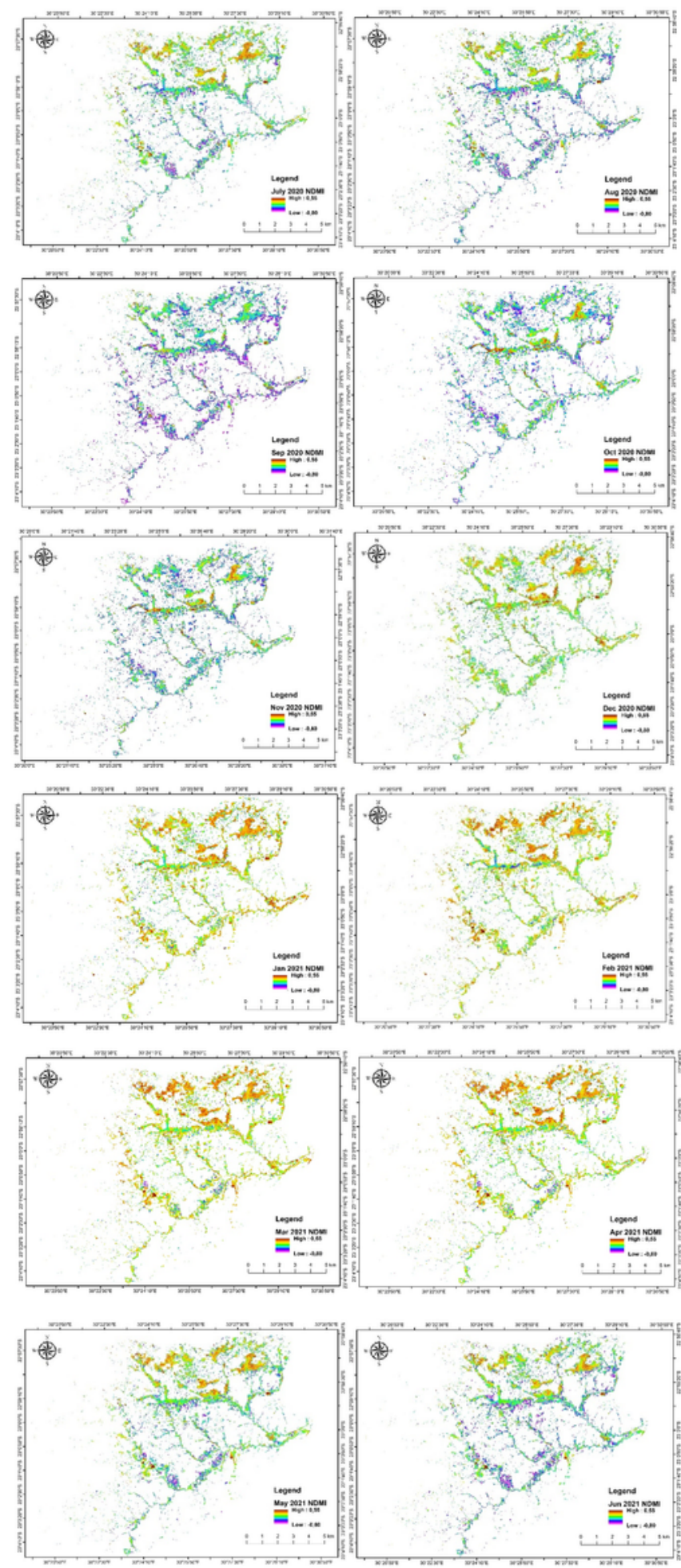

Figure 5

Monthly moisture variation depicted between July 2020 and June 2021 . 


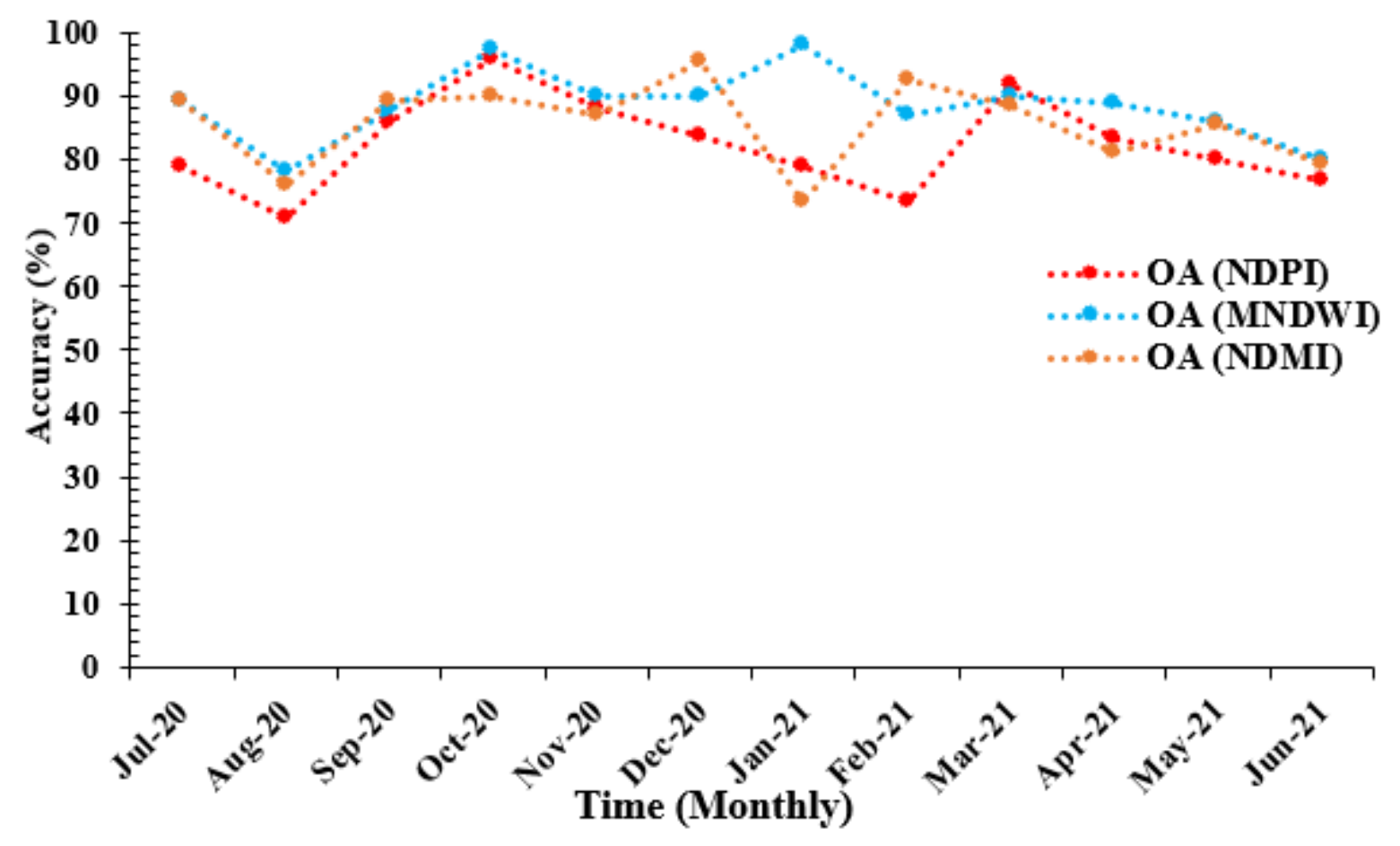

Figure 6

Overall classification accuracies achieved from different combination of the three algorithms (NDPI, NDMI and MNDWI) and Sentinel-2 sensors.

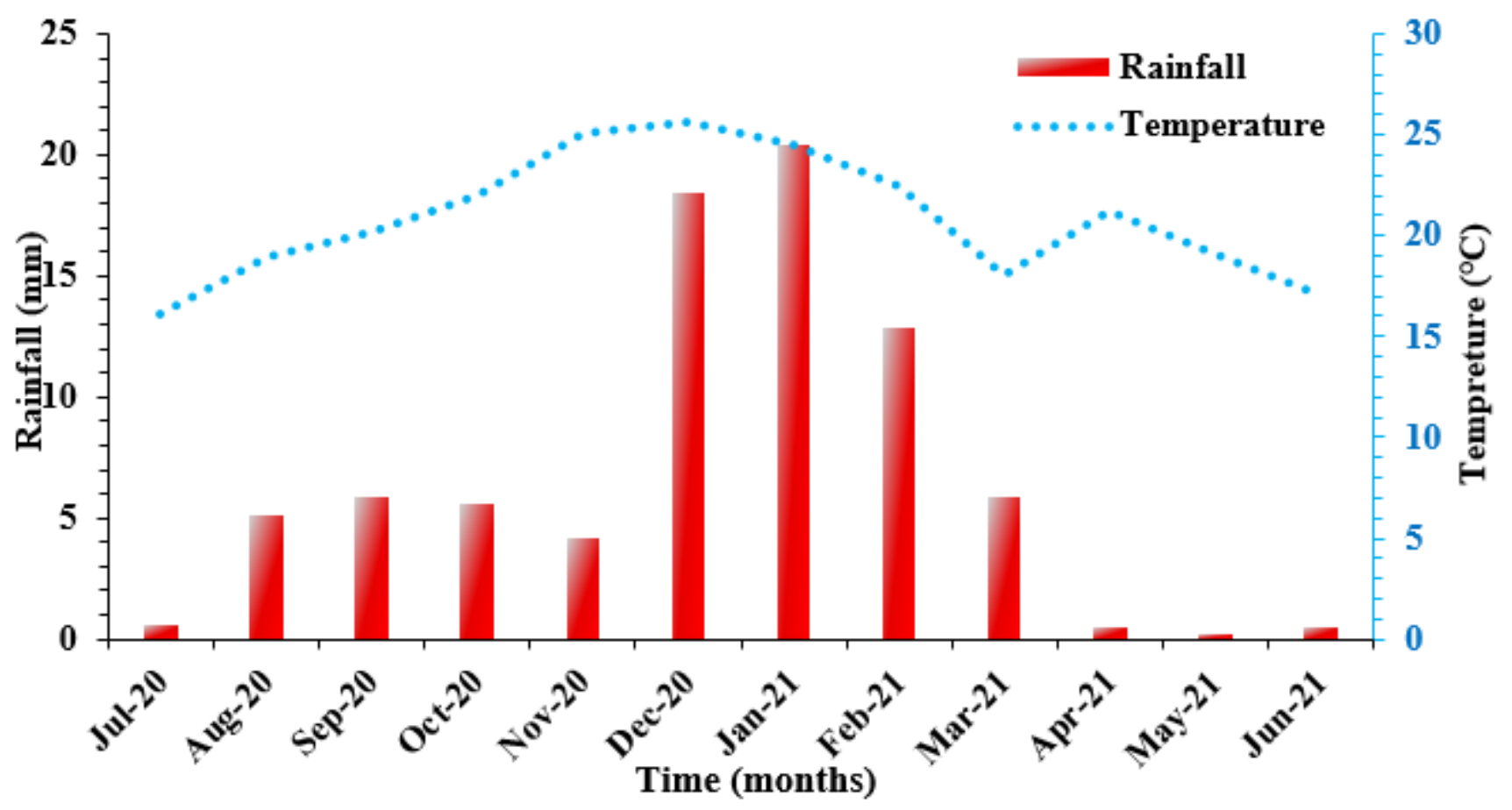

Figure 7

Monthly mean rainfall and temperature for the period between July 2020 and June 2021. 


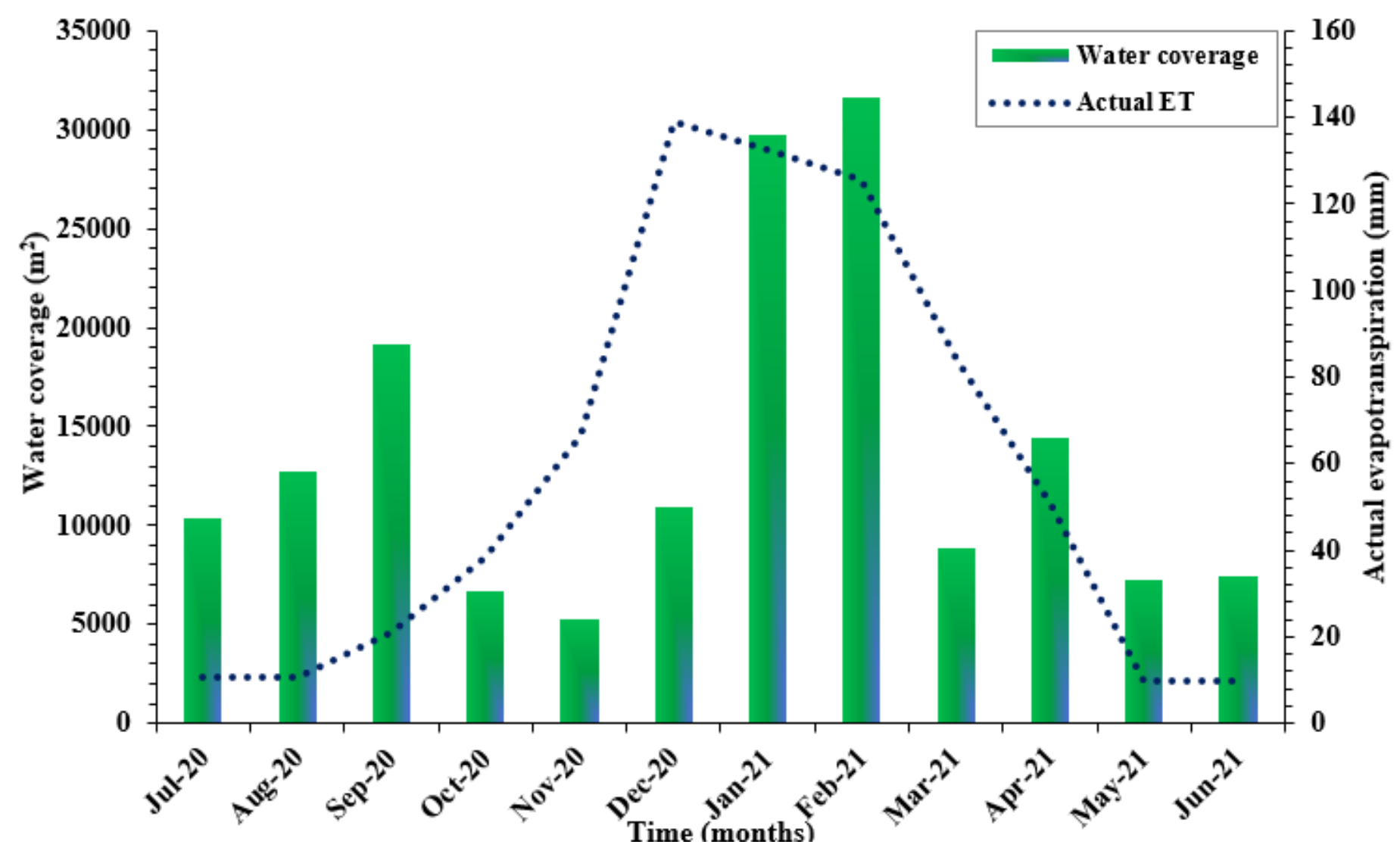

Figure 8

Relationship between the extracted water extent and actual evapotranspiration from July 2020 to June 2021.

\section{Supplementary Files}

This is a list of supplementary files associated with this preprint. Click to download.

- Table1.docx 